Review

\title{
Possible Role of Vitamin D in Celiac Disease Onset
}

\author{
Giorgia Vici $\odot$, Dalia Camilletti $@$ and Valeria Polzonetti * \\ School of Biosciences and Veterinary Medicine, University of Camerino, Via Gentile III da Varano, \\ 62032 Camerino, Italy; giorgia.vici@unicam.it (G.V.); dalia.camilletti@unicam.it (D.C.) \\ * Correspondence: valeria.polzonetti@unicam.it
}

Received: 26 February 2020; Accepted: 7 April 2020; Published: 10 April 2020

\begin{abstract}
Beside skeletal system maintenance and protection, possible extra-calcium roles of vitamin D have been recently described. In particular, studies have investigated possible roles of vitamin $\mathrm{D}$ as a key modulator of inflammation and immune mechanisms and of the intestinal mucosa barrier. In this regard, vitamin $\mathrm{D}$ has been considered as a factor that affects different conditions such as immune-mediated diseases. The new emerging role of vitamin $\mathrm{D}$ and its involvement in immune modulation has led it to be considered as a possible key factor involved in celiac disease (CD) onset. $\mathrm{CD}$ is a chronic immune-mediated enteropathy of the small intestine that is triggered by dietary gluten protein exposure in individuals who are genetically predisposed. However, along with gluten, other environmental factors are also involved in $\mathrm{CD}$ onset. The renewed interest in a molecule that offers great possibilities for new roles has led to an increase in studies, although there remains a lack of studies aimed at contextualizing the role of vitamin D on CD. This review aims to define the possible role of vitamin $\mathrm{D}$ in $\mathrm{CD}$ onset as it is presently understood, taking into account potential links among vitamin $\mathrm{D}$, the immune system and CD.
\end{abstract}

Keywords: vitamin D; celiac disease; celiac disease onset; environmental factors

\section{Introduction}

Vitamin D belongs to the steroid hormone family. It has two major forms, vitamin D3 (cholecalciferol) and vitamin D2 (ergocalciferol), both of which can be found in foods or supplements, although only vitamin D3 is synthetized in skin [1]. Indeed, vitamin D3 is mainly produced endogenously in the skin by converting 7-dehydrocholesterol through the action of ultraviolet light $\mathrm{B}$ (UVB) of the sun or other UVB sources [2,3]. Oral intake of vitamin D is generally limited (oily fish and eggs, vitamin D fortified food), while the majority of it is derived from UVB light action. This links its content not only to dietary intake, but above all to seasonal changes, sun exposure, geographic locations and skin pigmentation [4,5]. The steroid hormone precursor vitamin D3 is synthesized within skin and is biologically inactive. Two hydroxylation reactions are required to activate it. The first one forms the 25-hydroxyvitamin D3 [25(OH)D3 or calcidiol] in the liver, then 25(OH)D3 is converted to 1,25-dihydroxyvitamin D3 [1,25(OH)2D3 or calcitriol] by the $1 \alpha$-hydroxylase (CYP27B1) in the kidney. CYP27B1 enzyme is stimulated by parathyroid hormone (PTH) [4,5]. Vitamin D has been known for its role in the maintenance and safeguarding of skeletal system integrity. Indeed, biologically active vitamin $\mathrm{D}$ enhances calcium intestinal absorption by regulating calcium transport proteins in the small intestine, stimulating osteoclastic maturation and helping bone growth, which in turn supports collagen matrix mineralization $[1,3,6,7]$.

The vitamin D receptor (VDR), a nuclear receptor hormone, mediates the biological activity of 1,25(OH)2D3 [4,5]. The highly polymorphic VDR belongs to the steroid receptor super family and enables vitamin $\mathrm{D}$ to exert its genomic actions $[1,7,8]$.

Recently, vitamin D has received increased attention, as it was discovered that tissues and cells not involved in mineral and bone metabolism present VDR and vitamin D-activating enzymes. 
VDR has been reported to be expressed on cell types as antigen-presenting cells and lymphocytes, underlining a possible role of vitamin D as a key modulator of immune and inflammation mechanisms, and suggesting VDR gene polymorphisms to be markers of protection from or susceptibility to autoimmune diseases $[3,7,8]$. Pleiotropic actions on chronic diseases such as cardiovascular disease, diabetes, neurological disease and autoimmune disease are now under study. Over 900 genes have been reported as regulated by vitamin $\mathrm{D}[1,3]$. Although its effect on the immune system and infection is an emerging topic, there has been an increased understanding related to vitamin $\mathrm{D}$ as a regulator and signaling component on the immune system $[6,9,10]$.

Celiac disease $(C D)$ is a chronic small intestinal immune-mediated enteropathy triggered by exposure to dietary gluten proteins among individuals genetically predisposed, which affects around $1 \%$ of the general population [11-14]. CD is a unique autoimmune disease for which gluten has been identified as the environmental trigger. For the disease to occur, the key genetic elements human leukocyte antigen HLA-DQ2 and HLA-DQ8, and the involvement of autoantigen (tissue transglutaminase (tTG)) are required $[15,16]$.

The inducers of the disease are gluten and the alcohol-soluble gliadins it comprises, which are mainly present in specific cereals such as wheat, barley and rye [17].

In CD patients, the gluten contained in food products is broken down by specific gastrointestinal enzymes into peptides, which pass through the intestinal epithelial barrier to reach the mucosal lamina propria. The enzyme designated to convert gluten peptides is transglutaminase 2, which recognizes glutamine residues. Glutamine residues are converted into glutamic acid, leading the production of deamidated gluten peptides, which are now able to strongly bind to HLA-DQ2/-DQ8 molecules (the surface restriction elements for gluten-specific CD4+ T lymphocytes). Therefore, gluten peptides behave like antigens inducing an amplified immune response [18].

The cited HLA-DQ2/DQ8 molecules are the products of an expression of class II genes by the main histocompatibility complex (HLA system) [19].

Beyond genetically predisposed HLA-DQ2/DQ8 haplotypes, another characteristic in CD patients is the autoantibody response expressed against transglutaminase 2. The role of antibodies for transglutaminase 2 in the pathophysiology of $C D$ is not clear, but their serum concentration in CD patients is increased. Autoantibodies play a role in the diagnosis of $\mathrm{CD}$ and in monitoring the progression of the disease after beginning a gluten-free diet, which generally reduces serum autoantibodies after a period of months [20].

Moreover, celiac disease patients show an altered intestinal mucosa, due to the disassembly of enterocyte tight junctions (which, in physiological conditions, contributes to making the intestinal mucosa a barrier against external agents) [21].

Tight junctions are localized in the apical part of enterocytes and are responsible for their connection. Tight junctions are made up of integral membrane proteins such as occluding, claudins and scaffolding proteins (e.g., zonulin) [22]. Thanks to their capacity to connect enterocytes, tight junctions form a barrier to regulate the transfer of molecules through the intestine. Consequently, a variation in tight junction structure can lead to increased intestinal permeability [21].

The characteristic damage that occurs during CD due to gluten exposure develops gradually [23]. The appearance of lesions characterized by intensified increased intraepithelial lymphocytes, crypt hypertrophy and progressive villous atrophy are the first typical histologic sign of CD. At a macroscopic scale, celiac disease results in malabsorption, diarrhea, bloating and (to variable degrees) undernutrition [24]. According to Livshits et al., the most widespread intestinal clinical traits are malnutrition, chronic diarrhea and nutritional deficiencies. Today, these traits are disappearing, making way for extra-intestinal presentations such as skin, endocrine, skeletal, hepatic, hematological, thrombophylic, gynecological, fertility, dental, cutaneous, neurological and behavioral abnormalities [25]. Other extra-intestinal manifestations are osteopenia, osteoporosis, fractures, arthritis and arthralgia [26]. Currently, gluten-driven symptoms and injuries are occurring at more advanced ages, and latent, hypo-symptomatic or asymptomatic manifestations are becoming amply present [27]. 
Diagnosing CD requires several factors: the presence of clinical signs and symptoms, seropositivity for endomysial or tissue transglutaminase autoantibodies (tTGA), the existence of HLA-DQ2/DQ8 haplotypes and, last but not least, the appearance of histologic lesions characterized by increased intraepithelial lymphocytes, crypt hypertrophy and progressive villous atrophy. However, none of these four criteria are individually sufficient to confirm CD diagnosis [28].

While gluten exposure and the presence of specific HLA antigen genotypes are necessary elements for the occurrence of $\mathrm{CD}$, the disease risk is also strictly related to the timing or quantities of gluten consumed, and to the role of other potential pathophysiological factors. Therefore, the genetic predisposition is not enough on its own to be considered the triggering factor of the disease [29].

Aside from genetic predisposition, there are additional factors that play important roles in CD. Indeed, genetic background is a mandatory determinant of $C D$ development, but environmental factors (e.g., viral infections) also contribute, such as loss of intestinal barrier function, inappropriate adaptive immune response and an imbalance in gut microbiome [16]. The role of environmental factors in relation to celiac disease onset is of great interest. In this regard, Ludvigsoon and Green have introduced the concept of a "missing environmental factor" [30].

Other than gluten, which is the most important recognized environmental trigger factor, emerging data underline the possible roles of microbiota, time of gluten introduction to children, delivery method, history of breastfeeding, acute viral gastrointestinal infections and micronutrient deficiency in the development of $\mathrm{CD}[14,31,32]$. The emerging extra-calcium role of vitamin $\mathrm{D}$ and the increasing interest in its involvement in immune modulation led Tanpowpong and Camargo to postulate that, in genetically predisposed individuals, vitamin D deficiency can play an important role in CD onset in children. In particular, this deficiency can result in a dysregulated immune response that can contribute to an abnormal intestinal mucosa, increasing susceptibility to acute gastrointestinal infection [14]. Even if the role of vitamin $\mathrm{D}$ in celiac disease pathogenesis is not completely known, its potential role in immune regulation could link vitamin D deficiency to this condition, considering that vitamin and mineral deficiencies have been noted both in newly diagnosed CD patients and in CD patients with a gluten free diet (GFD) $[12,14,33]$.

This review aims to discuss the role of vitamin $\mathrm{D}$ in celiac disease onset, considering key findings from literature regarding vitamin D effects on the immune system, $25(\mathrm{OH}) \mathrm{D}$ plasma levels, vitamin $\mathrm{D}$ supplementation both in pregnancy and in infancy and CD development.

\section{Methods}

Searches at MEDLINE/PubMed were performed in February 2020 using a combination of keywords addressing "celiac disease", "vitamin D", "25-hydroxyvitamin D", "cholecarciferol", "vitamin supplement", "vitamin supplementation", "pregnancy" and "children", looking for articles published between 1 January 2010 and 7 February 2020. The following search algorithms were used:

((vitamin D) OR (vit. D) OR (25(OH)D) OR (25-hydroxyvitamin D) OR (cholecalciferol)) AND (celiac disease), which retrieved 428 papers, reduced to 213 with the "last 10 years" filter.

((vitamin D) OR (vit. D) OR (25(OH)D) OR (25-hydroxyvitamin D) OR (cholecalciferol)) AND (celiac disease) AND ((supplementation) OR (supplement)), which retrieved 80 papers, reduced to 57 with the "last 10 years" filter.

((vitamin D) OR (vit. D) OR (25(OH)D) OR (25-hydroxyvitamin D) OR (cholecalciferol)) AND (celiac disease) AND ((pregnancy) OR (pregnant)), which retrieved 21 papers, reduced to nine with the "last 10 years" filter.

((vitamin D) OR (vit. D) OR (25(OH)D) OR (25-hydroxyvitamin D) OR (cholecalciferol)) AND (celiac disease) AND ((infancy) OR (pediatric)), which retrieved 84 papers, reduced to 68 with the "last 10 years" filter.

((vitamin D) OR (vit. D) OR (25(OH)D) OR (25-hydroxyvitamin D) OR (cholecalciferol)) AND (celiac disease) AND ((molecular) OR (in vivo) OR (in vitro)), which retrieved 13 papers, reduced to six with the "last 10 years" filter. 
After compiling all of the papers obtained via the research algorithms and eliminating duplicates, the full text of the remaining 44 articles were extensively reviewed on the basis of originality and relevance of each paper to the scope of this review. Thirty-five papers were selected; moreover, 25 papers were added by searching the reference lists of the 35 papers reviewed. A total of 60 articles were considered for this review.

\section{Discussion}

\subsection{Vitamin D and Immune System}

The role of vitamin D on immune function has been the subject of increasing interest, and studies have reported effects on both innate and adaptive immune responses. Vitamin D exerts effects on different aspects of immune functions, and it helps in promoting innate immunity by maintaining and improving defences against infection whilst, in parallel, regulating T-cells and dendritic cells (DCs) via a possible role in the mitigation of T-cell-mediated autoimmune disease [6-9]. The enzyme to convert 25-hydroxyvitamin $D$ to its active form is expressed in macrophages and monocytes. It has been reported that vitamin D can participate in infection control thanks to its effect on macrophages, which enanch the antimicrobial effect. Indeed, the activation of Toll-like receptors regulates VDR expression, as bacteria lead Toll-like receptors to activate VDR expression and 25-hydroxyvitamin D- $1 \alpha$-hydroxylase activity to be increased, with the latter stimulating cathelicidins [6,34]. Moreover, vitamin D has shown an effect on dendritic cell activity by inhibiting monocyte differentiation into dentritic cells and decreasing IL-12 production. Effects on both B and T lymphocites have also been demonstrated. Influence on B-cell function has been reported as a consequence of differentiation and proliferation inhibition, apoptosis promotion and decreases in immunoglobulin production (autoantibodies included). It also reduces T-cell function by both decreasing $\mathrm{T}$ helper cell proliferation and differentiation, promoting a shift from a pro-inflammatory to a more tolerogenic immune status $[6,34]$. These new findings on the role of vitamin D have been underlined by studies reporting the increased risk of respiratory infection and of autoimmune disease in cases of low levels of vitamin D [9,35]. VDR is also expressed in the intestine, with a crucial role in cell proliferation, differentiation and apoptosis-induction regulation [36]. A literature revision by Masri underlined an association between vitamin D deficiency and incidences and activity of inflammatory bowel disease (IBD), with a focus on a possible role of vitamin D replacement therapy in IBD clinical practice, even if large intervention trials are needed [36]. Recently, the role of vitamin D in intestines has been described by Malaguarnera, who reported the role of vitamin $\mathrm{D}$ in the maintenance of gut homeostatis through a local synthesis of $1 \alpha, 25(\mathrm{OH}) 2 \mathrm{D} 3$ and VDR expression, emphasizing that an optimal $1 \alpha, 25(\mathrm{OH}) 2 \mathrm{D} 3$ status is fundamental, as it participates in several regulatory activities regarding not only calcium absorption but also infection protection, epithelial barrier function preservation and gut microbiota modulation. This role has received increased attention, as an unbalanced microbiota could be linked to several negative health disorders such as inflammation, allergic reactions, autoimmune diseases, heart diseases, obesity and metabolic syndrome [37].

Celiac disease is characterized by an immune response to undigested gliadin peptide fragments (e.g., pepsin-trypsin-resistant gliadin) in the small intestine. In susceptible individuals, the food-derived antigens of these fragments result in activation of the immune system and CD onset. In CD, ingested gluten leads to an immune response characterized by an interplay between innate and adaptive response. Gluten peptides are transferred to mucosal lamina propria and deamidated by tissue transglutaminase. The transfer from epithelial barrier to mucosal lamina propria could occur via either epithelial transcytosis or increased permeability of tight junctions. After the deamidation, gluten peptides bind to human leucocyte antigens (HLA-DQ2 and HLA-DQ8) on antigen-presenting cells. This step induces a response by activating CD4+ T-cells. An inflammatory response occurs, as CD4+ cells mainly secrete Th1 cytokines (as INF-gamma) that result in small bowel enteropathy, which is characterized by mucosal remodeling, villus atrophy and increasing cytotoxicity of intraepithelial lymphocytes or natural killer (NK) T-cells. Increases of intraepithelial lymphocytes and epithelial 
cell proliferations with crypt hyperplasia, as well as reduced enterocyte differentiation, characterize pathological lesions. In addition, CD4+ cells participate to the activation of B cells throughout Th2, resulting in the production of antibodies to gluten and transglutaminase [18,38-41].

Although the main external trigger is gluten, which is able to activate both innate and adaptive immune systems, the intestinal barrier plays a key role. Indeed, in susceptible individuals, an early disruption of the gut barrier will result in an increased permeability that could precede the onset of immune events induced by gluten $[18,38]$.

The intestinal barrier is a complex structure that aims to prevent harmful material from passing through intestinal mucosa that could reach the lamina propria. Its dynamic interaction with environmental factors such as pollutants, microorganisms and other materials are at the base of its crucial role. Its functionality depends on several factors, including epithelial layer integrity, gut-associated lymphoid tissue and intestinal microbiota homeostasis [18,38,42].

Tight junctions (TJs) are the major junctions responsible for intestinal mucosa barrier regulation. Indeed, under physiological conditions, they limit the passage of macromolecules (including gliadin peptides) across the intestinal barrier. TJs are multiprotein junctional complexes that regulate intestinal permeability. Injuries of TJs and consequent junction disassembly are considered initial processes that lead to the entry of gliadin peptide fragments and subsequent immune response activation. In this regard, increased intestinal permeability appears to be an early biologic change that precedes the onset of autoimmune diseases, including CD [38,43,44].

Gliadin has been reported as causing an increase in the permeability of the intercellular tight junctions of intestinal epithelial cells. This has been linked to an enhancement in zonulin release. Zonulin is a family of molecules that is responsible for the structural disassembly of tight junctions and consequently enhancement of intestinal permeability [16].

Lammers et al. have reported that the disassembly of gliadin-induced tight junctions is caused by the binding of gliadin to chemokine receptor CXCR3 and the subsequent MyD88-dependent release of zonulin. They also underlined that CXCR3 is expressed more abundantly at the intestinal level (i.e., epithelium and lamina propria) in patients with CD than in non-CD individuals $[43,44]$.

Fasano reported the upregulation of zonulin induced early in the disease by exposure to the disease's antigenic trigger gliadin impacts on TJs, causing an increased opening resulting in the passage of antigens (including gliadin) [45].

Thomas et al. proposed a model in which the increased intestinal permeability caused by gluten exposure and the release of zonulin gain access to submucosa through gliadin. Gliadin stimulates macrophages in a MyD88-dependent way to promote Th1 cytokine pooling (i.e., IL-12 p70, IL-15) through up-regulation of proinflammatory gene expression and cytokine secretion [46]. The role of vitamin $\mathrm{D}$ is of great interest in this context, as gut epithelial cells highly express vitamin D receptor (VDR), which mediates 1,25(OH)2D3 biological activity, and immunomodulatory properties have been reported $[47,48]$.

The expression and kinetics of vitamin D-related genes in human-activated $\mathrm{T}$ lymphocytes has been investigated by Baeke et al. They showed that 1,25(OH)2D3 effectively triggered VDR signaling, but only when introduced to T lymphocytes expressing high levels of VDR. These findings show that an enhanced degree of VDR signaling correlates with a stronger inhibition of cytokines, describing human T lymphocytes as direct targets of 1,25-dihydroxyvitamin D3 in the immune system [48].

In addition, the role of dendritic cells (DCs) in the interface between innate and adaptive immunity is of great interest in CD. Phenotype and function of DCs can be conditioned by several factors, one of which is represented by 1,25-dihydroxyvitamin D3 (1,25(OH)2D3). The potentially positive role of vitamin D on DCs has recently been underlined, demonstrating a strong relation between suboptimal vitamin D level and the occurrence and progression of many autoimmune diseases [49]. Ferreira et al. have demonstrated that in vitro treatment with 1,25-dihydroxyvitamin D3 alters the phenotype and behavior of murine bone marrow-derived dendritic cells, converting their immunogenicity into a tolerogenic profile for a reduction of T-cell responsiveness and an increased production of regulatory cytokines [50]. 
Another key aspect of the role of vitamin D in CD is its effect on TJ injuries.

A protective effect has been reported by several studies in different intestinal TJ injuries caused by dextran sulfate sodium and alcohol [51,52]. In the CD context, an interesting impact on TNF- $\alpha$ has been reported by Chen et al. They investigated the effect of 1,25(OH)2D3 on TNF- $\alpha$-induced barrier dysfunction in Caco- 2 cell monolayers. Their results describe a protective effect of vitamin $\mathrm{D}$, which suppresses NF-kb p65 by mediating the activation of the myosin light-chain kinase (MLCK)-P-MLC signaling pathway [53]. In particular, MLCK phosphorylates MLC, which is a mediator of actin dynamics, thus leading to a contraction of the actomyosin cytoskeleton and disruption of TJs in the intestine [54].

Dong et al. demonstrated that vitamin D 1,25 had a beneficial effect on TJ injuries induced by pepsin-trypsin-resistant gliadin (PT-G) both in a Caco-2 monolayer model and in a gluten-sensitized mouse model. They reported that in all their results, VD3 was able to suppress zonulin release signaling pathway activity, upregulate TJ protein expression and attenuate increases in Caco-2 monolayer permeability. Among three different studied concentrations $\left(10^{-7}, 10^{-8}\right.$ and $\left.10^{-9} \mathrm{M}\right), 10^{-8} \mathrm{M}$ showed a protective effect on PT-G-induced TJ injury, underlining that it may be dose dependent. At this concentration, vitamin D was linked to an upregulation of TJ protein expression and to zonulin release suppression. Moreover, this concentration inhibited the MyD88 expression involved in zonulin release. They confirmed these findings by performing an in vivo study using gluten-sensitized mice. The mice were sensitized with PT-G for 30 consecutive days, which resulted in significant increases in small intestinal permeability, significant decreases in TJ protein expression and MyD88-dependent zonulin release signaling pathway activation. A vitamin D3 oral treatment for 7 days attenuated these changes, confirming in vivo the protective role of vitamin D against PT-G-induced intestinal mucosal barrier injuries. The authors of this study did not explore the mechanism by which vitamin D blocks the zonulin release signaling pathway, but they did hypothesize that vitamin D3 may inhibit that pathway by binding to its ligand [38].

These findings support the hypothesis that vitamin D may have a key role in CD onset by being involved both in immune response regulation (through action on dendritic cells and T-cells, above all) and on intestinal permeability by regulating inflammatory cytokines and zonulin release pathway-two key factors related to CD.

\subsection{Celiac Disease and Enviromental Factors}

The importance of defining environmental factors that are able to influence $\mathrm{CD}$ onset relies on the possibility of improving and studying new strategies in terms of primary prevention. In this regard, factors that are able to influence $C D$ onset have been the subject of several studies. In particular, season of birth has become a new field of study, as a seasonally dependent fluctuation related to CD onset has been suggested (Table 1) [55-59]. A study conducted in Sweden showed an increased CD risk in children born during the summer compared with those born in winter. In particular, authors reported that in study group of 2151 children with verified CD, risk significantly increased in children ( $<2$ years old) born during summer, with this seasonal pattern maintained during 10-year epidemics of CD. Moreover, it was underlined that this seasonally dependent risk decreased with age, as if this exposure only exhibited an effect in the very first year of life. Study findings suggest a possible environmental exposure characterized by seasonal patterns, and authors has hypothesized a role of viral infection or time of gluten intake [55]. In addition, Lewy et al. examined the medical records of 431 children with CD (239 girls and 192 boys), and reported a seasonal pattern in CD that was different from the general population, with peaks in September. Moreover, different seasonality was found depending on age ( $<$ or $>24$ months), sex and family history of CD. The author linked study findings with perinatal virus infection as the trigger factor [56]. More recently, a case-control study conducted in Sweden using biopsy reports from 28 Swedish pathology departments with 144,522 controls matched for gender, age, calendar year and country reported an association between summer birth and increased risk of $\mathrm{CD}$, but the excess risk was small and largely limited to children diagnosed before age 2 . The authors 
of that study focused their attention on the need for further studies to test the possible mechanisms related to seasonality. In this context, they described not only the possible role infection could play in potentially increasing the risk of CD (e.g., by influencing microbiota and compromising mucosal barrier function), but also the role of low 25(OH)D levels. In particular, they considered both low $25(\mathrm{OH}) \mathrm{D}$ levels in mothers due to lack of UV light exposure during pregnancy, and in children at the time of gluten introduction and viral infection [57]. A population-based study conducted in the US analyzed CD prevalence in people living in northern latitudes compared with people living in southern latitudes. Data on gluten-related conditions were analyzed from the US National Health and Nutrition Examination Survey, from 2009 through 2014, using 22,277 participants that were 6 years and older. Authors reported a North-South gradient in CD with higher proportion on people living at latitudes of $35^{\circ}$ North or greater independently from race or ethnicity, socioeconomic status, or body mass index. This pattern resembles the north-south gradient in the disease occurrence of autoimmune diseases, including inflammatory bowel disease, multiple sclerosis and rheumatoid arthritis [58]. In a survey conducted at two Italian centers for CD in Rome and Bari using the data of CD patients born between 2003 and 2010 were retrospectively examined to investigate whether the season of birth could be associated with CD onset in Italy. In this study, 596 children were compared, with a reference group of 439,990 controls, and data showed that children born in the summer in Italy were at higher risk of developing CD. From these findings, the authors hypothesized that there could be some factors related to a pattern of seasonality. In particular, they underlined that children born in summer are introduced to gluten during the winter, with a concomitant increased probability of rotavirus infection. Moreover, it was highlighted that $25(\mathrm{OH}) \mathrm{D}$ levels can vary during the year due to different UV exposures [59].

Table 1. Seasonally dependent fluctuation related to celiac disease (CD) onset.

\begin{tabular}{|c|c|c|c|c|c|}
\hline & $\begin{array}{l}\text { Country } \\
\text { and Year }\end{array}$ & Design & Study Population & Method & Outcomes \\
\hline $\begin{array}{l}\text { Ivarsson } \\
\text { et al. [55] }\end{array}$ & $\begin{array}{l}\text { Sweden, } \\
2003\end{array}$ & $\begin{array}{l}\text { Retrospective } \\
\text { and } \\
\text { prospective } \\
\text { study }\end{array}$ & $\begin{array}{l}2151 \text { CD children } \\
\text { below } 15 \text { years of age. }\end{array}$ & $\begin{array}{l}\text { CD incidence rates were } \\
\text { calculated by month of birth, } \\
\text { stratified } \\
\text { for age at diagnosis. }\end{array}$ & $\begin{array}{l}\text { The risk for celiac disease was significantly higher } \\
\text { if born during summer compared } \\
\text { to winter in children below } 2 \text { years of age } \\
\text { at diagnosis. } \\
\text { This relative seasonal risk pattern prevailed during a } \\
\text { 10-year epidemic of celiac disease, although } \\
\text { incidence rates varied threefold. } \\
\text { The incidence was constantly higher among girls, } \\
\text { but boys showed a more pronounced seasonal } \\
\text { variation in risk. }\end{array}$ \\
\hline $\begin{array}{l}\text { Lewy et al. } \\
{[56]}\end{array}$ & $\begin{array}{l}\text { Israel, } \\
2009\end{array}$ & $\begin{array}{l}\text { Retrospective } \\
\text { study }\end{array}$ & $\begin{array}{l}431 \text { CD children } \\
\text { ( } 239 \text { girls, } 192 \text { boys). } \\
138 \text { girls and } 81 \text { boys } \\
\text { were under the age of } \\
24 \text { months. }\end{array}$ & $\begin{array}{l}\text { Medical records were } \\
\text { analyzed to obtain both statistical } \\
\text { significance and parameters of } \\
\text { rhythms. }\end{array}$ & $\begin{array}{l}\text { Boys and girls with CD were found to have different } \\
\text { seasonality of month of birth. } \\
\text { Girls diagnosed before age } 24 \text { months (peak } \\
\text { July-August) had a different seasonality birth from } \\
\text { those diagnosed after age } 24 \text { months (no rhythm) } \\
\text { and showed a different seasonality from } \\
\text { boys with diagnosis above } 24 \text { months (peak July). } \\
\text { Different seasonality was found in children with a } \\
\text { family history of CD. }\end{array}$ \\
\hline $\begin{array}{l}\text { Lebwohl } \\
\text { et al. [57] }\end{array}$ & USA, 2013 & $\begin{array}{l}\text { Case-control } \\
\text { study }\end{array}$ & $\begin{array}{l}351,403 \text { biopsy reports, } \\
\text { of which } 29,096 \text { from } \\
\text { patients with CD. Up } \\
\text { to } 5 \text { controls for each } \\
\text { CD individual were } \\
\text { identified by } \\
\text { Statistics Sweden } \\
\text { (total: } 144,522 \text { ). }\end{array}$ & $\begin{array}{l}\text { The association between summer } \\
\text { birth (March-August) and later } \\
\text { CD diagnosis was examined } \\
\text { through conditional logistic } \\
\text { regression. }\end{array}$ & $\begin{array}{l}54.10 \% \text { of individuals with CD vs } 52.75 \% \text { of controls } \\
\text { were born in the summer months. Summer birth } \\
\text { associated with a small increased risk of later CD. } \\
\text { Stratifying CD patients according to age at diagnosis, } \\
\text { the highest OR was found in those diagnosed before } \\
\text { age } 2 \text { years, while summer birth was not associated } \\
\text { with a CD diagnosis in later childhood (age } 2-18 \\
\text { years), but had a marginal effect on the risk of CD } \\
\text { in adulthood. }\end{array}$ \\
\hline $\begin{array}{l}\text { Unalp-Arida } \\
\text { et al. [58] }\end{array}$ & USA, 2017 & $\begin{array}{l}\text { Population- } \\
\text { based study }\end{array}$ & $\begin{array}{l}22,277 \text { participants } \\
6 \text { years and older. }\end{array}$ & $\begin{array}{l}\text { Analyzed data on gluten-related } \\
\text { conditions from the US National } \\
\text { Health and Nutrition Examination } \\
\text { Survey, from } 2009 \text { through } 2014 \\
\text { identifying persons with CD. }\end{array}$ & $\begin{array}{l}0.7 \% \text { of participants were found to have CD. } \\
\text { Celiac disease was more common among individuals } \\
\text { who lived at latitudes of } 35-39^{\circ} \text { North or at latitudes } \\
\text { of } 40^{\circ} \text { North or more than individuals who lived at } \\
\text { latitudes below } 35^{\circ} \text { North, independent of race or } \\
\text { ethnicity, socioeconomic status or body mass index. }\end{array}$ \\
\hline $\begin{array}{l}\text { Capriati } \\
\text { et al. [59] }\end{array}$ & Italy, 2015 & $\begin{array}{l}\text { Retrospective } \\
\text { study }\end{array}$ & $\begin{array}{l}596 \text { CD patients } \\
\text { children (age range } 3.5) \\
\text { compared with } \\
439,990 \text { controls }\end{array}$ & $\begin{array}{l}\text { Survey conducted } \\
\text { at two Italian referral centers for } \\
\mathrm{CD} \text { in Rome and Bari. The CD } \\
\text { database was created to enable } \\
\text { retrospective examination of the } \\
\text { data of all the consecutive patients } \\
\text { born between } 2003 \text { and } 2010 \text { who } \\
\text { had received a diagnosis of } C D \text {. }\end{array}$ & $\begin{array}{l}\text { A summer birth preponderance was observed in } \mathrm{CD} \\
\text { patients compared to controls. } \\
\text { Stratifying the case by gender, the summer birth } \\
\text { preponderance was maintained for females. }\end{array}$ \\
\hline
\end{tabular}




\subsection{Vitamin D Status in Celiac Disease}

In order to evaluate the involvment of vitamin $\mathrm{D}$ in $\mathrm{CD}$ onset, attention was focused on vitamin $\mathrm{D}$ status not only after CD diagnosis, but also before, especially during pregnancy and first years of life (Table 2).

In 2011, O'Malley reviewed the vitamin D statuses and supplementations in a pediatric population with gastrointestinal diseases, reporting that children with gastrointestinal disease were more likely to have a vitamin D deficiency, possibly due to malabsorption. The review also highlighted the importance of vitamin D status monitoring of children, and the need for possible supplementation in some instances [60].

The importance of introducing routine testing to evaluate vitamin deficiencies led Imam et al. to conduct a retrospective medical record review of CD patient, measuring fat-soluble vitamin levels at the time of diagnosis in order to identify the frequency of deficiencies. However, data obtained showed that fat-soluble vitamin $\mathrm{D}$ deficiencies were uncommon in pediatric $\mathrm{CD}$, even if the study had some limitations (such as the small sample size (83 patients) and data coming from a single tertiary center) [61]. Similar results were obtained by Villanueva et al. that found no differences in vitamin D status between $C D$ children and no-CD children in a retrospective study of 74 prepubertal children (age 3-12 years old) divided into $24 \mathrm{CD}$ and 50 no-CD [62]. Further, Lerner et al. compared the vitamin D status of CD children (Israeli CD children and Spanish CD children, group 1 and group 5, respectively) to children with no-specific abominal pain (group 2), their parents (group 3) and Spanish adult CD patients (group 4). No vitamin D deficiency was found in the children. Conversely, in the adult $\mathrm{CD}$ population, a significant vitamin $\mathrm{D}$ deficiency was reported. This was explained by the authors as being related to the fact that children with $C D$ had an increased intake in terms of vitamin $D$, due to the routine supplementation during the first year of their lives, as well as increased sun exposure and GFD compliance. Interestingly, they observed that vitamin D deficiency was age dependent, but this seems not to be related to degree of small bowel injury in CD. From these findings they concluded that a routine check of vitamin D status in CD patients is of fundamental importance, especially in adults [63]. A study was conducted to investigate if the prevalence of autoimmune diseases was higher in patients with $C D$ and low vitamin $D$ than in patients with $C D$ but normal vitamin $D$. Both groups had a similar prevalence, however psoriasis risk was higher in the low vitamin $\mathrm{D}$ group. Although this study reported that low vitamin $\mathrm{D}$ was not predictive of autoimmine disease among CD individuals, it was underlined that vitamin D deficiency is common in $C D$, and that assessment of its values should be taken into account in clinical practice [64]. The importance of nutrient assessment in CD was also underlined by Caruso in a review that aimed to evaluate the impact of $\mathrm{CD}$ on iron, folate, vitamin B12, vitamin D and calcium [11]. Micronutrients are commonly below optimal levels in treated CD, and this deficiency could be related to extra-intestinal symptoms or signs [11,12].

In order to study a possible correlation among micronutrient deficiency in $\mathrm{CD}$, serum tissue transglutaminase (tTG) immunoglobulin A (IgA) antibody titers and degree of mucosal damage at diagnosis, Deora et al. evaluated the prevalence of micronutrient deficiences in children both at diagnosis and at 6 and 18 months after the start of a GFD. Examining the medical records of 140 children with $C D$, a $70 \%$ deficit in vitamin $\mathrm{D}$ was found. In addition to this, the data showed no correlation between degree of villous atrophy or serum titers of anti-tTG IgA molecules and micronutrient deficiency. Moreover, almost all micronutrient deficiences found at the diagnosis were reported to have normalized after 6 and 10 months of a GFD. Only vitamin D and ferritin still remain under optimal levels after 18 months, highlighting the importance of their long-term assessments. In this regard, the authors of the study reported that vitamin D status evaluation should be performed annually in children [65].

As nutritional deficiences are commonly found in gastointestinal disease, Ahlavat et al. reviewed the prevalence of vitamin D deficiency in pediatric gastrointestinal disease. They reported that even if the exact role of vitamin D is not fully understood, the actual knownledge in bone health and the role in immune regulation mean that determining vitamin $\mathrm{D}$ status is very important to screening 
for diseases such as IBD and celiac diasease. From a practical point of view, they screened for low vitamin D status at disease onset and, if needed, treated for any level greater than $30 \mathrm{ng} / \mathrm{mL}$ but less than $100 \mathrm{ng} / \mathrm{mL}$. However, large randomized controlled trials are needed in order to further investigate the role of vitamin D in disease remission and the maintenance of optimal 25(OH)D levels [33]. Recently, a cross-sectional study conducted with the aim of screening for vitamin $\mathrm{D}$ status reported no significant difference between newly diagnosed CD patients and no-CD controls in regards to vitamin D status. However, inadequante $25(\mathrm{OH}) \mathrm{D}$ levels were found in both groups. Moreover, vitamin $\mathrm{D}$ levels were highly associated with estimated vitamin $\mathrm{D}$ intake in both the CD and control groups. Form these findings, the authors recommended a vitamin D status screening in children at diagnosis time [66].

The impact of vitamin D status on CD onset has also been investigated in pregnant women, as low concentrations of it have been associated with offspring autoimmune disease. In particular, Marild et al. tested whether low maternal and neonatal 25(OH)D levels could be a predictor of increased CD risk in a cohort of pregnant norwegian women. In particular, mid-pregnancy and post-partum blood analysis and cord plasma were performed, comparing data of 416 children who developed CD and 570 children without nCD. In addition to this, mothers and children were genotyped for established celiac disease and vitamin D metabolism variants. Obtained results showed no significant difference of $25(\mathrm{OH}) \mathrm{D}$ levels between the two group, and genetic variants for deficiency did not associate with CD. The authors concluded that even if they could not exclude the presence of unmeasured confounders, level of 25(OH)D seems not to be associated with pediatric CD onset. However, randomized controlled trials will be needed to further investigate this topic [9]. In 2019, a cross-sectional study was conducted to evaluate whether severe vitamin D deficiency is assosiated with CD by evaluating 200 Saudi adolescent girls. Data obtained showed CD as a potential a risk for severe vitamin D deficiency and, above all, that low levels of vitamin $\mathrm{D}(<12.5 \mathrm{nmol} / \mathrm{L})$, in absence of obvious causes, could be a sign of the need for CD screening [67].

In terms of supplementation, Bittker reported that oral vitamin D consumption among children could be a significant risk factor in inducing CD. Bittker related this to the fact that vitamin D tends to elevate the activity of Th2 cytokine, which upregulates immune reactions to external stimuli, reporting that vitamin $\mathrm{D}$ has been described as a risk factor for allergic diseases including asthma and atopic dermatitis, with high comorbidity with CD [68]. Recently, the same author reported that the "missing environmental factor" could be significant oral vitamin D exposure with its consequent increase in plasma. Oral vitamin D in large doses upregulates cytokines, chemokines and Toll-like receptors that are also upregulated in CD. Moreover, epidemiologically higher CD prevalence has been reported in countries with aggressive supplementation policies [69]. As vitamin D could be considered an immunomodulator, and its role in CD has been recieved increased importance, Bittker conducted a case-control epidemiological survey among parents living in the US with at least one biological child between 3 and 12 years old to determine if nine varibales could be associated with $\mathrm{CD}$ in children. Among these, vitamin D drop exposure in infancy and vitamin supplement exposure between 2-3 years were evaluated. Data obtained from 332 children diagnosed with CD (cases) and 241 without CD (controls) suggest that infants who received oral vitamin D drops for longer than 3 months were at increased risk of subsequently developing CD [70]. On the contrary, a longitudinal prospective observational study on 6627 children reported that maternal use of dietary supplements during pregnancy is not associated with CD. In particular, maternal use of vitamin $\mathrm{D}, n-3$ fatty acids and iron were not associated with CD risk, concluding that dietary supplementation during pregnancy could be a tool to improve nutrient intake [71]. 
Table 2. Vitamin D status in celiac disease.

\begin{tabular}{|c|c|c|c|c|c|c|}
\hline & $\begin{array}{l}\text { Country } \\
\text { and Year }\end{array}$ & Design & Study Population & Methods & Vit. D Supplement & Outcomes \\
\hline $\begin{array}{l}\text { Imam et al. } \\
\text { [61] }\end{array}$ & USA, 2014 & $\begin{array}{l}\text { Retrospective } \\
\text { study }\end{array}$ & $\begin{array}{l}83 \mathrm{CD} \text { patients: } 51 \text { girls and } 32 \text { boys } \\
\text { (average age at diagnosis, } 12.8 \text { and 13.0, } \\
\text { respectively) }\end{array}$ & $\begin{array}{l}\text { Medical record review of CD patients and } \\
\text { fat-soluble vitamin levels measured at } \\
\text { diagnosis between } 1995 \text { and } 2012 \text { at Mayo } \\
\text { Clinic. }\end{array}$ & $\begin{array}{l}\text { None receiving vitamin } \\
\text { supplements at the time of } \\
\text { diagnosis. }\end{array}$ & $\begin{array}{l}\text { Average } 25(\mathrm{OH}) \mathrm{D} \text { vitamin levels } 32.8 \mathrm{ng} / \mathrm{mL} \text {; } \\
9 \text { patients had mild-to-moderate vitamin D deficiency, } \\
31 \text { patients showed insufficiency of } 25(\mathrm{OH}) \mathrm{D} \text {. }\end{array}$ \\
\hline $\begin{array}{l}\text { Villanueva } \\
\text { et al. [62] }\end{array}$ & USA, 2012 & $\begin{array}{l}\text { Retrospective } \\
\text { study }\end{array}$ & $\begin{array}{l}24 \text { prepubertal CD children and } 50 \\
\text { no-CD (age, 3-12 years) }\end{array}$ & $\begin{array}{l}\text { 25(OH)D level } \\
\text { measured by chemiluminescence } \\
\text { immunoassay. Height and body weight } \\
\text { measured to calculate BMI. }\end{array}$ & No supplementation. & $\begin{array}{l}\text { No difference in } 25(\mathrm{OH}) \mathrm{D} \text { level between } \mathrm{CD} \text { and no-CD. } \\
\text { Non-obese } \mathrm{CD} \text { had a significantly higher } 25(\mathrm{OH}) \mathrm{D} \\
\text { level than the obese no-CD. } \\
\text { No difference in } 25(\mathrm{OH}) \mathrm{D} \text { level in non-obese. }\end{array}$ \\
\hline $\begin{array}{l}\text { Lerner et al. } \\
\text { [63] }\end{array}$ & $\begin{array}{l}\text { Israel and } \\
\text { Spain, } \\
2012\end{array}$ & $\begin{array}{l}\text { Case-control } \\
\text { study }\end{array}$ & $\begin{array}{l}272 \text { individuals } \\
\text { in five groups. } \\
\text { Group 1: } 51 \text { Israeli children with CD } \\
\text { (age, } 6 \pm 4 \text { years); Group 5: } 59 \text { Spanish } \\
\text { children with CD (age, } \\
4 \pm 4 \text { years); } \\
\text { Group 2: } 56 \text { Israeli children with } \\
\text { nonspecific abdominal pain (age, } \\
8 \pm 5 \text { years); } \\
\text { Group 3: } 84 \text { adults, } \\
\text { parents of group 2 (age, } 39 \pm 8 \text { years); } \\
\text { Group 4: } 22 \text { Spanish adults with CD } \\
\text { (age, } 44 \pm 13 \text { years). }\end{array}$ & $\begin{array}{l}\text { Vitamin D serum levels investigated } \\
\text { in CD populations } \\
\text { compared to children } \\
\text { with nonspecific abdominal pain, their } \\
\text { parents and } \\
\text { Spanish adult } \mathrm{CD} \text { patients. } \\
\text { 25(OH)D checked by chemiluminescent } \\
\text { immunoassays. }\end{array}$ & No supplementation. & $\begin{array}{l}\text { Groups } 5 \text { and } 1 \text { had the highest levels compared to } \\
\text { groups } 4 \text { and } 3 \text {. Levels in groups } 1 \text { and } 2 \text { were } \\
\text { comparable. Concerning } \\
\text { 25(OH)D sera levels, only the difference between } \\
\text { groups } 5 \text { and } 4 \text { was statistically significant. } \\
\text { Vitamin D sera levels negatively correlated with age. }\end{array}$ \\
\hline $\begin{array}{l}\text { Tavakkoli } \\
\text { et al. [64] }\end{array}$ & USA, 2013 & $\begin{array}{l}\text { Retrospective } \\
\text { cross-sectional } \\
\text { study }\end{array}$ & $530 \mathrm{CD}$ adult patients & $\begin{array}{l}\text { Compared patients with normal vitamin D } \\
\text { level ( } \geq 30 \mathrm{mg} / \mathrm{dL}) \text { against those with } \\
\text { vitamin D insufficiency }(20-29 \mathrm{mg} / \mathrm{dL}) \text { and } \\
\text { vitamin D deficiency }(<20 \mathrm{mg} / \mathrm{dL}) \text { with } \\
\text { regards to prevalence of autoimmune } \\
\text { disorders. }\end{array}$ & $\begin{array}{l}\text { Patients were not excluded from } \\
\text { the study if they were taking } \\
\text { vitamin D supplements, but } \\
\text { there was no knowledge of } \\
\text { supplementation. }\end{array}$ & $\begin{array}{l}25 \% \text { showed vitamin D deficiency. Similar prevalence } \\
\text { of AD } \\
\text { among those with normal vitamin D }(11 \%) \text {, } \\
\text { insufficiency }(9 \%) \text { and deficiency }(12 \%) . \\
\text { Vitamin D deficiency was not associated with AD. } \\
\text { Risk of psoriasis was higher in patients with vitamin D } \\
\text { deficiency. }\end{array}$ \\
\hline $\begin{array}{l}\text { Deora et al. } \\
\text { [65] }\end{array}$ & $\begin{array}{l}\text { Canada, } \\
2017\end{array}$ & $\begin{array}{l}\text { Single-center } \\
\text { cohort study }\end{array}$ & $\begin{array}{l}\text { Medical records of } 140 \mathrm{CD} \text { children } \\
\text { (mean age at diagnosis } \\
7.8 \pm 4.01 \text { years) }\end{array}$ & $\begin{array}{l}\text { Analysis of the medical records of all } \\
\text { children with CD. Routine celiac blood tests } \\
\text { carried out at diagnosis } \\
6 \text { months after starting GFD, then on an } \\
\text { annual basis. Histopathological changes of } \\
\text { duodenal biopsies at diagnosis } \\
\text { documented using modified MARSH } \\
\text { classification. Diet } \\
\text { assessment with proper teaching of GFD at } \\
\text { diagnosis, } 6 \text { months and } 18 \text { months after } \\
\text { diagnosis. }\end{array}$ & $\begin{array}{l}\text { During each clinic visit, an } \\
\text { experienced dietitian evaluated } \\
\text { the nutritional status and need } \\
\text { for micronutrient } \\
\text { supplementations. }\end{array}$ & $\begin{array}{l}70 \% \text { of subjects with serum vitamin } \mathrm{D} \text { deficiency. No } \\
\text { correlation between micronutrient deficiencies at } \\
\text { diagnosis and serum tTG IgA antibody titers or the } \\
\text { degree of villous atrophy. } \\
\text { The majority of serum levels of micronutrients } \\
\text { normalized after } 6 \text { months after beginning GFD, except } \\
\text { for vitamin D, which improved but remained } \\
\text { subnormal. }\end{array}$ \\
\hline
\end{tabular}


Table 2. Cont

\begin{tabular}{|c|c|c|c|c|c|c|}
\hline & $\begin{array}{l}\text { Country } \\
\text { and Year }\end{array}$ & Design & Study Population & Methods & Vit. D Supplement & Outcomes \\
\hline $\begin{array}{l}\text { Ahlawat } \\
\text { et al. [66] }\end{array}$ & USA, 2019 & $\begin{array}{l}\text { Cross-sectional } \\
\text { study }\end{array}$ & $\begin{array}{l}38 \text { newly diagnosed } C D \text { patients } \\
(10.4 \pm 3.0 \text { years old }) \text { and } 82 \text { controls } \\
(11.2 \pm 4.2 \text { years old }) .\end{array}$ & $\begin{array}{l}25(\mathrm{OH}) \mathrm{D} \\
\text { levels drawn in children with newly } \\
\text { diagnosed CD compared with } \\
\text { pediatric outpatients with functional } \\
\text { abdominal complaints. Anthropometric } \\
\text { data and vitamin D intake based on milk } \\
\text { and multivitamin ingestion were recorded. }\end{array}$ & $\begin{array}{l}\text { Patients were excluded if they } \\
\text { used } \\
\text { single-preparation vitamin D } \\
\text { supplements within } 3 \text { months } \\
\text { of study } \\
\text { enrollment. Multivitamin use } \\
\text { was allowed. }\end{array}$ & $\begin{array}{l}\text { Both groups were similar except for average daily D } \\
\text { intake and BMI. } \\
\text { No statistical difference in mean } 25(\mathrm{OH}) \mathrm{D} \text { levels } \\
\text { between CD and controls. Both groups had high } \\
\text { percentages of suboptimal D status. } \\
25(\mathrm{OH}) \mathrm{D} \text { levels significantly correlated with age } \\
(r=-0.262) \text { and estimated vitamin D intake }(r=0.361) \text {. }\end{array}$ \\
\hline $\begin{array}{l}\text { Mårild et al. } \\
\text { [9] }\end{array}$ & $\begin{array}{l}\text { Norwey, } \\
2017\end{array}$ & $\begin{array}{l}\text { Case-control } \\
\text { study }\end{array}$ & $\begin{array}{l}416 \text { children who developed celiac } \\
\text { disease, } 570 \text { randomly selected } \\
\text { controls and their mothers }\end{array}$ & $\begin{array}{l}\text { 25(OH)D examined in maternal blood from } \\
\text { mid-pregnancy, post-partum } \\
\text { and cord plasma. } \\
\text { Mothers and children genotyped for } \\
\text { established celiac disease and vitamin D } \\
\text { metabolism variants. }\end{array}$ & $\begin{array}{l}\text { Participants completed a food } \\
\text { frequency questionnaire covering } \\
\text { the period from start of } \\
\text { pregnancy until completion } \\
\text { around week 22, to evaluate their } \\
\text { vitamin D intake while also } \\
\text { considering supplements. }\end{array}$ & $\begin{array}{l}\text { No significant difference in average } 25(\mathrm{OH}) \mathrm{D} \text { between } \\
\text { cases } \\
\text { and controls and no significant linear trend. } \\
\text { Genetic variants } \\
\text { for vitamin D deficiency were not associated with CD. }\end{array}$ \\
\hline $\begin{array}{l}\text { Sulimani } \\
{[67]}\end{array}$ & $\begin{array}{l}\text { Saudi } \\
\text { Arabia, } \\
2019\end{array}$ & $\begin{array}{l}\text { Cross-sectional } \\
\text { study }\end{array}$ & $\begin{array}{l}200 \text { adolescent females aged 13-19 years } \\
\text { old with vitamin D deficiency }\end{array}$ & $\begin{array}{l}\text { Female adolescent screened for IgA tTG } \\
\text { (anti-tissue transglutaminase antibodies). }\end{array}$ & No vitamin D supplement. & $\begin{array}{l}\text { Of the } 200 \text { girls, } 9(4.5 \%) \text { were positive for IgA tTG } \\
\text { antibodies; all of whom had serum } 25(\mathrm{OH}) \mathrm{D} \\
<12.5 \mathrm{nmol} / \mathrm{L} \text {. A strong } \\
\text { significant inverse association was found between tTG } \\
\text { antibody levels and serum } 25(\mathrm{OH}) \mathrm{D}(R=-0.53) \text { among } \\
\text { antibody } \\
\text { negative participants. Positive IgA tTG antibodies were } \\
37.2 \text { times higher among participants with } 25(\mathrm{OH}) \mathrm{D}< \\
12.5 \mathrm{nmml} / \mathrm{L} \text { than those whose vitamin D status was } \\
\text { higher. }\end{array}$ \\
\hline Bittker [70] & USA, 2019 & $\begin{array}{l}\text { Case-control } \\
\text { study }\end{array}$ & $\begin{array}{l}332 \text { parents with CD children }+241 \\
\text { parents with no-CD children (controls) }\end{array}$ & $\begin{array}{l}\text { An Internet-based survey was conducted } \\
\text { among parents living in the US with at least } \\
\text { one biological child between } 3 \text { and } 12 \text { years } \\
\text { old in order to determine if } 9 \text { variables are } \\
\text { associated with CD, among these: } \\
\text { vitamin D drop exposure in infancy and } \\
\text { vitamin D supplement } \\
\text { exposure between 2-3 years old. }\end{array}$ & $\begin{array}{l}\text { Two questions examined } \\
\text { supplemental vitamin } D \\
\text { exposure. One focused on the } \\
\text { duration of exposure } \\
\text { to vitamin D drops in infancy. } \\
\text { The other on vitamin } \\
\text { D supplementation between } \\
\text { 2-3 years of age. }\end{array}$ & $\begin{array}{l}\text { In this dataset, only vitamin } \mathrm{D} \\
\text { drops administered for more than } 3 \text { months was } \\
\text { associated with CD children. }\end{array}$ \\
\hline $\begin{array}{l}\text { Yang et al. } \\
\text { [71] }\end{array}$ & $\begin{array}{l}\text { USA, } \\
\text { Finland, } \\
\text { German, } \\
\text { Sweden, } \\
2017\end{array}$ & $\begin{array}{l}\text { Longitudinal } \\
\text { prospective } \\
\text { observational } \\
\text { study }\end{array}$ & 6627 children (years range $0.9-10.0$ ) & $\begin{array}{l}\text { Examined the association between maternal } \\
\text { use of vitamin } D, n-3 \text { fatty acids (FA) and Fe } \\
\text { supplements during pregnancy and risk for } \\
\text { CD autoimmunity (CDA) and CD in the } \\
\text { offspring. }\end{array}$ & $\begin{array}{l}\text { Use of supplements containing } \\
\text { vitamin D, } n-3 \text { FA and Fe was } \\
\text { recalled by } 66 \%, 17 \% \text { and } 94 \% \text { of } \\
\text { mothers, respectively, at } \\
3-4 \text { months post-partum. } \\
\text { The mean cumulative intake over } \\
\text { the entire pregnancy was } 2014 \mu \mathrm{g} \\
\text { vitamin D (SD 2045 } \mu \mathrm{g}), 111 \mathrm{~g} n-3 \\
\text { FA (SD } 303 \mathrm{~g} \text { ) and } 8806 \mathrm{mg} \mathrm{Fe} \\
\text { (SD 7017 mg). }\end{array}$ & $\begin{array}{l}\text { Of } 6627 \text { enrolled children, } 1136 \text { developed CDA at a } \\
\text { median } 3.1 \text { years of age (range } 0.9-10 \text { ) and } 409 \\
\text { developed CD at a median } 3.9 \text { years of age } \\
\text { (range 1.2-11). } \\
\text { No statistically significant association between the } \\
\text { intake of vitamin D, } n-3 \text { FA or Fe, and risk for CDA or } \\
\text { CD. Dietary supplementation during pregnancy did not } \\
\text { seem to modify the risk for the disease in the offspring. }\end{array}$ \\
\hline
\end{tabular}

$\mathrm{AD}$ = autoimmune disorder; $\mathrm{BMI}=$ body mass index; $\mathrm{CD}=$ celiac disease $\mathrm{CDA}$ = celiac disease autoimmunity; $\mathrm{FA}=$ fatty acids; $\mathrm{GFD}=$ gluten free diet; $\mathrm{tTG}=$ anti-tissue transglutaminase; $25(\mathrm{OH}) \mathrm{D}=25$-hydroxyvitamin $\mathrm{D}$. 


\subsection{Vitamin D and International Guidelines}

Even if the interest in the role of vitamin $\mathrm{D}$ in $\mathrm{CD}$ is increasing, previously reported data have been controversial, and specific studies and indications regarding optimal serum levels and supplementation strategies are still lacking. Controversy remians regarding the optimal level of serum vitamin $\mathrm{D}$, with governamental agencies reporting sufficiency at levels of $25(\mathrm{OH}) \mathrm{D}>20 \mathrm{ng} / \mathrm{mL}$ ( $>50 \mathrm{nmol} / \mathrm{L}$ ). However, evidence related to both skeletal and non-skeletal outcomes has defined the vitamin D deficiency threshold as $30 \mathrm{nmol} / \mathrm{L}[66,72-74]$.

The American College of Gastroenterology reccomended the assessment of micronutrient deficiences for, but not limited to, iron, folic acid, vitamin D and Vitamin B12 in newly diagnosed CD [75]. The British Society of Gastroenterology (BSG) CD guidelines suggest measuring calcium, alkaline phosphatase, vitamin D levels and parathyroid hormone both at diagnosis and when neccessery [76]. Specifically for pediatric patients, the North American Society for Pediatric Gastroenterology, Hepatology and Nutrition (NASPGHAN) reccomends vitamin D assessment at diagnosis and annually [77]. An Italian consensus suggests serum vitamin $\mathrm{D}$ levels be evaluated in CD patients at diagnosis and after 6-12 months of GFD if deficiency has been found [78]. A panel of experts published reccomendations for managing $C D$ in children, and suggested screening vitamin $D$ at diagnosis; however, the quality of evidence was considered low and the strenght weak. They suggested considering age-appropriate counseling regarding calcium and vitamin D supplementation at diagnosis and during follow up (evidence grade high, statement strength strong) [79]. The Endocrine Society Clinical Practice Guideline advises evaluating vitamin D status in patients at risk of deficiency, suggesting supplementation either with vitamin D2 or D3 for deficient patients [72].

Recommendations from the National Institute for Health and Care Excellence (NICE) on the recognition, assessment and management of celiac disease based on systematic reviews of available evidence suggests the possible needs of vitamin D supplementation in cases of insufficient dietary intake. However, they reported very low-quality randomized controlled trials the basis of this recommendation [80].

Governmental agencies, including the Institute of Medicine (IOM) in North America and the European Food Safety Authority (EFSA) in the EU, have set the estimated average daily intake of vitamin D for healthy adults (with minimal or no sunlight exposure) at $400 \mathrm{IU}$ per day [81,82]. In particular, IOM stated that for vitamin D (assuming minimal sun exposure), the estimated average requirement (EAR) is $400 \mathrm{IU} /$ day for ages older than 1 year, and the recommended dietary allowance (RDA) is $600 \mathrm{IU} /$ day for ages 1 to 70 years and $800 \mathrm{IU} /$ day for 71 years and older. The tolerable upper intake level (UL) ranges from 1000 to 4000 IU daily for vitamin D: 1000 IU for infants 0-6 months, 1500 IU infants 6-12 months, 2500 IU for children 1-3 years, 3000 IU for children 4-8 years and $4000 \mathrm{IU}$ for children 9 years and older [81]. An EFSA panel set the adequante intake (AI) for adults at $15 \mu \mathrm{g} /$ day, for children aged 1-17 years at $15 \mu \mathrm{g} /$ day and for infants aged 7-11 months at $10 \mu \mathrm{g} /$ day. For pregnant and lactating women, the panel set the same AI as for non-pregnant non-lactating women, (i.e., $15 \mu \mathrm{g} /$ day). The UL for adults (including pregnant and lactating women) was set at $100 \mu \mathrm{g} /$ day. In children and adolescents aged 11-17 years, the UL was adapted to $100 \mu \mathrm{g} /$ day. For children aged 1-10 years a UL of $50 \mu \mathrm{g} /$ day was proposed, and for infants it was set at $25 \mu \mathrm{g} / \mathrm{day}$. A subsequent update set the upper limit at $25 \mu \mathrm{g} /$ day for infants aged up to 6 months, but a UL of $35 \mu \mathrm{g} /$ day for infants 6-12 months [82-84].

However, specific guidelines and indications relating to both optimal vitamin D status and supplementation specifically related to $\mathrm{CD}$ in terms of primary and secondary prevention are still lacking. More studies, and randomized controlled trials in particular, are needed to further and better evaluate the role of vitamin $\mathrm{D}$ in $\mathrm{CD}$ onset and during the follow up.

\section{Conclusions}

Considering the importance of environmental factors in CD pathophysiology, several aspects are currently under study in order to find a possible association with CD onset. Presently, one 
important focus of attention relies on birth seasonality, as CD risk seems to increase in infants born during the summer. This aspect could be related to other factors, such as time of gluten ingestion, virus infections, different UV exposures or mother's vitamin D status during pregnancy, as well as a concomitant presence of these factors. In particular, the emerging extra-calcium role of vitamin $\mathrm{D}$ and the increasing interest on its impact on the immune system and intestinal barrier permeability leads to its consideration as an important factor possibly involved in $\mathrm{CD}$ onset.

However, there have only been a few fragmentary studies, with different focuses and studied populations. Moreover, the role of supplementation is still uncertain. It is common to routinely consider vitamin D supplementation; however, this has sometimes been considered ineffective.

In light of this, clarifying the role of vitamin D is of great importance. There is a need for larger studies that would take into account variables that can have a role in CD onset (i.e., vitamin $\mathrm{D}$ levels of pregnant women, vitamin D supplementation and/or UV exposure), as well as involving different countries. This would be of fundamental importance in order to better explore possible associations and, in particular, to study and evaluate the possible role of vitamin D that could therefore play a key role in terms of prevention and be part of possible new $\mathrm{CD}$ prevention strategies.

Author Contributions: Conceptualization, V.P. and G.V.; methodology, V.P. and G.V.; writing-original draft preparation, G.V.; writing-review and editing, V.P., G.V. and D.C.; All authors have read and agreed to the published version of the manuscript.

Funding: This research received no external funding.

Conflicts of Interest: The authors declare no conflict of interest.

\section{References}

1. Kamen, D.L.; Tangpricha, V. Vitamin D and molecular actions on the immune system: Modulation of innate and autoimmunity. J. Mol. Med. 2010, 88, 441-450. [CrossRef] [PubMed]

2. Barrea, L.; Muscogiuri, G.; Laudisio, D.; Di Somma, C.; Salzano, C.; Pugliese, G.; de Alteriis, G.; Colao, A.; Savastano, S. Phase angle: A possible biomarker to quantify inflammation in subjects with obesity and 25 (OH) D deficiency. Nutrients 2019, 11, 1747. [CrossRef] [PubMed]

3. Barrea, L.; Savanelli, M.C.; Di Somma, C.; Napolitano, M.; Megna, M.; Colao, A.; Savastano, S. Vitamin D and its role in psoriasis: An overview of the dermatologist and nutritionist. Rev. Endocr. Metab. Disord. 2017, 18, 195-205. [CrossRef] [PubMed]

4. He, L.; Zhou, M.; Li, Y.C. Vitamin D/Vitamin D Receptor Signaling Is Required for Normal Development and Function of Group 3 Innate Lymphoid Cells in the Gut. iScience 2019, 17, 119-131. [CrossRef] [PubMed]

5. Altieri, B.; Muscogiuri, G.; Barrea, L.; Mathieu, C.; Vallone, C.V.; Mascitelli, L.; Bizzaro, G.; Altieri, V.M.; Tirabassi, G.; Balercia, G. Does vitamin D play a role in autoimmune endocrine disorders? A proof of concept. Rev. Endocr. Metab. Disord. 2017, 18, 335-346. [CrossRef] [PubMed]

6. Murdaca, G.; Tonacci, A.; Negrini, S.; Greco, M.; Borro, M.; Puppo, F.; Gangemi, S. Emerging role of vitamin D in autoimmune diseases: An update on evidence and therapeutic implications. Autoimmun. Rev. 2019, 18, 102350. [CrossRef]

7. Wu, D.; Lewis, E.D.; Pae, M.; Meydani, S.N. Nutritional Modulation of Immune Function: Analysis of Evidence, Mechanisms, and Clinical Relevance. Front. Immunol. 2018, 9, 3160. [CrossRef]

8. San-Pedro, J.I.; Bilbao, J.R.; Perez de Nanclares, G.; Vitoria, J.C.; Martul, P.; Castano, L. Heterogeneity of vitamin D receptor gene association with celiac disease and type 1 diabetes mellitus. Autoimmunity 2005, 38, 439-444. [CrossRef]

9. Marild, K.; Tapia, G.; Haugen, M.; Dahl, S.R.; Cohen, A.S.; Lundqvist, M.; Lie, B.A.; Stene, L.C.; Stordal, K. Maternal and neonatal vitamin D status, genotype and childhood celiac disease. PLoS ONE 2017, 12, e0179080. [CrossRef]

10. Schwalfenberg, G.K. Solar radiation and vitamin D: Mitigating environmental factors in autoimmune disease. J. Environ. Public Health 2012, 2012, 619381. [CrossRef]

11. Caruso, R.; Pallone, F.; Stasi, E.; Romeo, S.; Monteleone, G. Appropriate nutrient supplementation in celiac disease. Ann. Med. 2013, 45, 522-531. [CrossRef] [PubMed] 
12. Vici, G.; Belli, L.; Biondi, M.; Polzonetti, V. Gluten free diet and nutrient deficiencies: A review. Clin. Nutr. 2016, 35, 1236-1241. [CrossRef] [PubMed]

13. Theethira, T.G.; Dennis, M.; Leffler, D.A. Nutritional consequences of celiac disease and the gluten-free diet. Expert Rev. Gastroenterol. Hepatol. 2014, 8, 123-129. [CrossRef] [PubMed]

14. Tanpowpong, P.; Camargo, C.A. Early-life vitamin D deficiency and childhood-onset coeliac disease. Public Health Nutr. 2014, 17, 823-826. [CrossRef]

15. Barker, J.M.; Liu, E. Celiac disease: Pathophysiology, clinical manifestations, and associated autoimmune conditions. Adv. Pediatr. 2008, 55, 349-365. [CrossRef]

16. Caio, G.; Volta, U.; Sapone, A.; Leffler, D.A.; De Giorgio, R.; Catassi, C.; Fasano, A. Celiac disease: A comprehensive current review. BMC Med. 2019, 17, 142. [CrossRef]

17. Lerner, A.; Agmon-Levin, N.; Shapira, Y.; Gilburd, B.; Reuter, S.; Lavi, I.; Shoenfeld, Y. The thrombophilic network of autoantibodies in celiac disease. BMC Med. 2013, 11, 89. [CrossRef]

18. Cukrowska, B.; Sowinska, A.; Bierla, J.B.; Czarnowska, E.; Rybak, A.; Grzybowska-Chlebowczyk, U. Intestinal epithelium, intraepithelial lymphocytes and the gut microbiota - Key players in the pathogenesis of celiac disease. World J. Gastroenterol. 2017, 23, 7505-7518. [CrossRef]

19. Yakovlevich, K.L.; Valerievna, S.M.; Aleksandrovna, K.V.; Nicolaevna, Z.I.; Arturovna, A.R.; Valerievna, Z.E.; Dmitrievna, K.L.; Victorovna, I.A. Genetic Characteristics of Children with Celiac Disease Living in the South of Russia. Медицинский вестникСеверного Кавказа 2019, 14. [CrossRef]

20. Niro, S.; D’Agostino, A.; Fratianni, A.; Cinquanta, L.; Panfili, G. Gluten-Free Alternative Grains: Nutritional Evaluation and Bioactive Compounds. Foods 2019, 8, 208. [CrossRef]

21. König, J.; Wells, J.; Cani, P.D.; García-Ródenas, C.L.; MacDonald, T.; Mercenier, A.; Whyte, J.; Troost, F.; Brummer, R.-J. Human intestinal barrier function in health and disease. Clin. Transl. Gastroenterol. 2016, 7, e196. [CrossRef] [PubMed]

22. Delbue, D.; Cardoso-Silva, D.; Branchi, F.; Itzlinger, A.; Letizia, M.; Siegmund, B.; Schumann, M. Celiac Disease Monocytes Induce a Barrier Defect in Intestinal Epithelial Cells. Int. J. Mol. Sci. 2019, 20, 5597. [CrossRef] [PubMed]

23. Belei, O.; Dobrescu, A.; Heredea, R.; Iacob, E.R.; David, V.; Marginean, O. Histologic recovery among children with celiac disease on a gluten-free diet. A long-term follow-up single-center experience. Arch. Med. Sci. AMS 2018, 14, 94. [CrossRef] [PubMed]

24. Almeida, R.M.; da Silva, Z.D.L.; Leite, F.B.; de Medeiros Nóbrega, Y.K. Antinuclear Antibodies Patterns in Patients with Celiac Disease. Biomed. J. 2019, 1, 3.

25. Livshits, O.E.; Shauol, R.; Reifen, R.; Matthias, T.; Lerner, A. Can celiac disease present along with childhood obesity. Int. J. Celiac. Dis. 2017, 5, 19-23.

26. Popp, A.; Mäki, M. Gluten-Induced Extra-Intestinal Manifestations in Potential Celiac Disease-Celiac Trait. Nutrients 2019, 11, 320. [CrossRef]

27. Lerner, A.; Matthias, T. Extraintestinal manifestations of CD: Common pathways in the gut-remote organs' axes. Intern. J. Celiac. Dis. 2017, 5, 24-27.

28. Agardh, D.; Lee, H.-S.; Kurppa, K.; Simell, V.; Aronsson, C.A.; Jörneus, O.; Hummel, M.; Liu, E.; Koletzko, S.; Group, T.S. Clinical features of celiac disease: A prospective birth cohort. Pediatrics 2015, 135, 627-634. [CrossRef]

29. Aronsson, C.A.; Lee, H.-S.; af Segerstad, E.M.H.; Uusitalo, U.; Yang, J.; Koletzko, S.; Liu, E.; Kurppa, K.; Bingley, P.J.; Toppari, J. Association of gluten intake during the first 5 years of life with incidence of celiac disease autoimmunity and celiac disease among children at increased risk. JAMA 2019, 322, 514-523. [CrossRef]

30. Ludvigsson, J.F.; Green, P.H. The missing environmental factor in celiac disease. J. Med. 2014, 371, $1285-1294$. [CrossRef]

31. Kupfer, S.S.; Jabri, B. Pathophysiology of celiac disease. Gastrointest Endosc. Clin. 2012, 22, 639-660. [CrossRef] [PubMed]

32. Tanpowpong, P.; Obuch, J.C.; Jiang, H.; McCarty, C.E.; Katz, A.J.; Leffler, D.A.; Kelly, C.P.; Weir, D.C.; Leichtner, A.M.; Camargo, C.A., Jr. Multicenter study on season of birth and celiac disease: Evidence for a new theoretical model of pathogenesis. J. Pediatrics 2013, 162, 501-504. [CrossRef] [PubMed]

33. Ahlawat, R.; Weinstein, T.; Pettei, M.J. Vitamin D in pediatric gastrointestinal disease. Curr. Opin. Pediatr. 2017, 29, 122-127. [CrossRef] [PubMed] 
34. Prietl, B.; Treiber, G.; Pieber, T.R.; Amrein, K. Vitamin D and immune function. Nutrients 2013, 5, $2502-2521$. [CrossRef]

35. Miraglia, M.D.G.; Indolfi, C.; Strisciuglio, C. Vitamin D: Immunomodulatory Aspects. J. Clin. Gastroenterol. 2018, 52, S86-S88. [CrossRef]

36. Masri, O.A.; Chalhoub, J.M.; Sharara, A.I. Role of vitamins in gastrointestinal diseases. World J. Gastroenterol. 2015, 21, 5191-5209. [CrossRef]

37. Malaguarnera, L. Vitamin D and microbiota: Two sides of the same coin in the immunomodulatory aspects. Int. Immunopharmacol. 2020, 79, 106112. [CrossRef]

38. Dong, S.; Singh, T.P.; Wei, X.; Yao, H.; Wang, H. Protective Effect of 1,25-Dihydroxy Vitamin D3 on Pepsin-Trypsin-Resistant Gliadin-Induced Tight Junction Injuries. Dig. Dis. Sci. 2018, 63, 92-104. [CrossRef]

39. Lionetti, E.; Catassi, C. New clues in celiac disease epidemiology, pathogenesis, clinical manifestations, and treatment. Int. Rev. Immunol. 2011, 30, 219-231. [CrossRef]

40. Dewar, D.; Pereira, S.P.; Ciclitira, P.J. The pathogenesis of coeliac disease. Int. J. Biochem. Cell Biol. 2004, 36, 17-24. [CrossRef]

41. Ferretti, G.; Bacchetti, T.; Masciangelo, S.; Saturni, L. Celiac disease, inflammation and oxidative damage: A nutrigenetic approach. Nutrients 2012, 4, 243-257. [CrossRef] [PubMed]

42. Fasano, A. All disease begins in the (leaky) gut: Role of zonulin-mediated gut permeability in the pathogenesis of some chronic inflammatory diseases. F1000Research 2020. [CrossRef] [PubMed]

43. Lammers, K.M.; Lu, R.; Brownley, J.; Lu, B.; Gerard, C.; Thomas, K.; Rallabhandi, P.; Shea-Donohue, T.; Tamiz, A.; Alkan, S.; et al. Gliadin induces an increase in intestinal permeability and zonulin release by binding to the chemokine receptor CXCR3. Gastroenterology 2008, 135. [CrossRef] [PubMed]

44. Lammers, K.M.; Khandelwal, S.; Chaudhry, F.; Kryszak, D.; Puppa, E.L.; Casolaro, V.; Fasano, A. Identification of a novel immunomodulatory gliadin peptide that causes interleukin-8 release in a chemokine receptor CXCR3-dependent manner only in patients with coeliac disease. Immunology 2011, 132, 432-440. [CrossRef]

45. Fasano, A. Intestinal permeability and its regulation by zonulin: Diagnostic and therapeutic implications. Clin. Gastroenterol. Hepatol. 2012, 10, 1096-1100. [CrossRef]

46. Thomas, K.E.; Sapone, A.; Fasano, A.; Vogel, S.N. Gliadin stimulation of murine macrophage inflammatory gene expression and intestinal permeability are MyD88-dependent: Role of the innate immune response in Celiac disease. J. Immunol. 2006, 176, 2512-2521. [CrossRef]

47. Du, J.; Chen, Y.; Shi, Y.; Liu, T.; Cao, Y.; Tang, Y.; Ge, X.; Nie, H.; Zheng, C.; Li, Y.C. 1, 25-Dihydroxyvitamin D protects intestinal epithelial barrier by regulating the myosin light chain kinase signaling pathway. Inflamm. Bowel. Dis. 2015, 21, 2495-2506. [CrossRef]

48. Baeke, F.; Korf, H.; Overbergh, L.; van Etten, E.; Verstuyf, A.; Gysemans, C.; Mathieu, C. Human T lymphocytes are direct targets of 1, 25-dihydroxyvitamin D3 in the immune system. J. Steroid Biochem. Mol. Biol. 2010, 121, 221-227. [CrossRef]

49. Saul, L.; Mair, I.; Ivens, A.; Brown, P.; Samuel, K.; Campbell, J.D.; Soong, D.Y.; Kamenjarin, N.; Mellanby, R.J. 1, 25-Dihydroxyvitamin D3 restrains CD4+ T cell priming ability of CD11c+ dendritic cells by upregulating expression of CD31. Front. Immunol. 2019, 10, 600. [CrossRef]

50. Ferreira, G.B.; van Etten, E.; Verstuyf, A.; Waer, M.; Overbergh, L.; Gysemans, C.; Mathieu, C. 1, 25-Dihydroxyvitamin D3 alters murine dendritic cell behaviour in vitro and in vivo. Diabetes/Metab. Res. Rev. 2011, 27, 933-941. [CrossRef]

51. Zhao, H.; Zhang, H.; Wu, H.; Li, H.; Liu, L.; Guo, J.; Li, C.; Shih, D.Q.; Zhang, X. Protective role of 1, 25 (OH) 2 vitamin D 3 in the mucosal injury and epithelial barrier disruption in DSS-induced acute colitis in mice. BMC Gastroenterol. 2012, 12, 57. [CrossRef] [PubMed]

52. Chen, S.-W.; Ma, Y.-Y.; Zhu, J.; Zuo, S.; Zhang, J.-L.; Chen, Z.-Y.; Chen, G.-W.; Wang, X.; Pan, Y.-S.; Liu, Y.-C. Protective effect of 1,25-dihydroxyvitamin D3 on ethanol-induced intestinal barrier injury both in vitro and in vivo. Toxicol. Lett. 2015, 237, 79-88. [CrossRef] [PubMed]

53. Chen, S.; Zhu, J.; Chen, G.; Zuo, S.; Zhang, J.; Chen, Z.; Wang, X.; Li, J.; Liu, Y.; Wang, P. 1,25-Dihydroxyvitamin D3 preserves intestinal epithelial barrier function from TNF- $\alpha$ induced injury via suppression of NF-kB p65 mediated MLCK-P-MLC signaling pathway. Biochem. Biophys. Res. Commun. 2015, 460, 873-878. [CrossRef] 
54. Guo, S.; Chen, S.; Ma, J.; Ma, Y.; Zhu, J.; Ma, Y.; Liu, Y.; Wang, P.; Pan, Y. Escherichia coli Nissle 1917 Protects Intestinal Barrier Function by Inhibiting NF-kB-Mediated Activation of the MLCK-P-MLC Signaling Pathway. Mediat. Inflamm. 2019, 2019, 5796491. [CrossRef] [PubMed]

55. Ivarsson, A.; Hernell, O.; Nyström, L.; Persson, L.Å. Children born in the summer have increased risk for coeliac disease. J. Epidemiol. Community Health 2003, 57, 36-39. [CrossRef] [PubMed]

56. Lewy, H.; Meirson, H.; Laron, Z. Seasonality of birth month of children with celiac disease differs from that in the general population and between sexes and is linked to family history and environmental factors. J. Pediatric Gastroenterol. Nutr. 2009, 48, 181-185. [CrossRef] [PubMed]

57. Lebwohl, B.; Green, P.H.; Murray, J.A.; Ludvigsson, J.F. Season of birth in a nationwide cohort of coeliac disease patients. Arch. Dis. Child. 2013, 98, 48-51. [CrossRef]

58. Unalp-Arida, A.; Ruhl, C.E.; Brantner, T.L.; Murray, J.A. Lower prevalence of celiac disease and gluten-related disorders in persons living in southern vs northern latitudes of the United States. Gastroenterology 2017, 152, 1922-1932.e2. [CrossRef]

59. Capriati, T.; Francavilla, R.; Castellaneta, S.; Ferretti, F.; Diamanti, A. Impact of the birth's season on the development of celiac disease in Italy. Eur. J. Pediatr. 2015, 174, 1657-1663. [CrossRef]

60. O’Malley, T.; Heuberger, R. Vitamin D status and supplementation in pediatric gastrointestinal disease. J. Spec. Pediatric Nurs. 2011, 16, 140-150. [CrossRef]

61. Imam, M.H.; Ghazzawi, Y.; Murray, J.A.; Absah, I. Is it necessary to assess for fat-soluble vitamin deficiencies in pediatric patients with newly diagnosed celiac disease? J. Pediatric Gastroenterol. Nutr. 2014, 59, 225-228. [CrossRef] [PubMed]

62. Villanueva, J.; Maranda, L.; Nwosu, B.U. Is vitamin D deficiency a feature of pediatric celiac disease? J. Pediatr. Endocrinol. Metab. 2012, 25, 607-610. [CrossRef] [PubMed]

63. Lerner, A.; Shapira, Y.; Agmon-Levin, N.; Pacht, A.; Ben-Ami Shor, D.; Lopez, H.M.; Sanchez-Castanon, M.; Shoenfeld, Y. The clinical significance of $25 \mathrm{OH}-$ Vitamin D status in celiac disease. Clin. Rev. Allergy Immunol. 2012, 42, 322-330. [CrossRef] [PubMed]

64. Tavakkoli, A.; DiGiacomo, D.; Green, P.H.; Lebwohl, B. Vitamin D status and concomitant autoimmunity in celiac disease. J. Clin. Gastroenterol. 2013, 47, 515-519. [CrossRef] [PubMed]

65. Deora, V.; Aylward, N.; Sokoro, A.; El-Matary, W. Serum vitamins and minerals at diagnosis and follow-up in children with celiac disease. J. Pediatric Gastroenterol. Nutr. 2017, 65, 185-189. [CrossRef]

66. Ahlawat, R.; Weinstein, T.; Markowitz, J.; Kohn, N.; Pettei, M.J. Should We Assess Vitamin D Status in Pediatric Patients With Celiac Disease? J. Pediatr. Gastroenterol. Nutr. 2019, 69, 449-454. [CrossRef]

67. Sulimani, R.A. Celiac disease and severe vitamin D deficiency: The case for anti-tissue transglutaminase antibody screening. Arch. Osteoporos. 2019, 14, 30. [CrossRef]

68. Bittker, S. Exposure to excessive oral vitamin D in youth: A risk factor for celiac disease in later life. J. Allergy Asthma 2015, 2. [CrossRef]

69. Bittker, S.S. Elevated Levels of 1, 25-Dihydroxyvitamin D in Plasma as a Missing Risk Factor for Celiac Disease. Clin. Exp. Gastroenterol. 2020, 13, 1. [CrossRef]

70. Bittker, S.S.; Bell, K.R. Potential risk factors for celiac disease in childhood: A case-control epidemiological survey. Clin. Exp. Gastroenterol. 2019, 12, 303. [CrossRef]

71. Yang, J.; Tamura, R.N.; Aronsson, C.A.; Uusitalo, U.M.; Lernmark, Å.; Rewers, M.; Hagopian, W.A.; She, J.-X.; Toppari, J.; Ziegler, A.G. Maternal use of dietary supplements during pregnancy is not associated with coeliac disease in the offspring: The Environmental Determinants of Diabetes in the Young (TEDDY) study. Br. J. Nutr. 2017, 117, 466-472. [CrossRef] [PubMed]

72. Holick, M.F.; Binkley, N.C.; Bischoff-Ferrari, H.A.; Gordon, C.M.; Hanley, D.A.; Heaney, R.P.; Murad, M.H.; Weaver, C.M. Evaluation, treatment, and prevention of vitamin D deficiency: An Endocrine Society clinical practice guideline. J. Clin. Endocrinol. Metab. 2011, 96, 1911-1930. [CrossRef] [PubMed]

73. Montagnani, A.; Nardi, R.; Cercignani, M.; Verdiani, V. Potential role of vitamin D in prevention of skeletal and extraskeletal diseases in older people. Ital. J. Med. 2015, 10, 29-35. [CrossRef]

74. Macdonald, H.M.; Reid, I.R.; Gamble, G.D.; Fraser, W.D.; Tang, J.C.; Wood, A.D. 25-Hydroxyvitamin D threshold for the effects of vitamin D supplements on bone density: Secondary analysis of a randomized controlled trial. J. Bone Miner. Res. 2018, 33, 1464-1469. [CrossRef]

75. Rubio-Tapia, A.; Hill, I.D.; Kelly, C.P.; Calderwood, A.H.; Murray, J.A. American College of Gastroenterology clinical guideline: Diagnosis and management of celiac disease. Am. J. Gastroenterol. 2013, 108, 656. [CrossRef] 
76. Ludvigsson, J.F.; Bai, J.C.; Biagi, F.; Card, T.R.; Ciacci, C.; Ciclitira, P.J.; Green, P.H.; Hadjivassiliou, M.; Holdoway, A.; Van Heel, D.A. Diagnosis and management of adult coeliac disease: Guidelines from the British Society of Gastroenterology. Gut 2014, 63, 1210-1228. [CrossRef]

77. Hill, I.D.; Fasano, A.; Guandalini, S.; Hoffenberg, E.; Levy, J.; Reilly, N.; Verma, R. NASPGHAN clinical report on the diagnosis and treatment of gluten-related disorders. J. Pediatric Gastroenterol. Nutr. 2016, 63, 156-165. [CrossRef]

78. Saggese, G.; Vierucci, F.; Prodam, F.; Cardinale, F.; Cetin, I.; Chiappini, E.; de'Angelis, G.L.; Massari, M.; Del Giudice, E.M.; Del Giudice, M.M. Vitamin D in pediatric age: Consensus of the Italian Pediatric Society and the Italian Society of Preventive and Social Pediatrics, jointly with the Italian Federation of Pediatricians. Ital. J. Pediatrics 2018, 44, 51. [CrossRef]

79. Snyder, J.; Butzner, J.D.; DeFelice, A.R.; Fasano, A.; Guandalini, S.; Liu, E.; Newton, K.P. Evidence-informed expert recommendations for the management of celiac disease in children. Pediatrics 2016, 138, e20153147. [CrossRef]

80. Downey, L.; Houten, R.; Murch, S.; Longson, D. Recognition, assessment, and management of coeliac disease: Summary of updated NICE guidance. Bmj 2015, 351, h4513. [CrossRef]

81. Institute of Medicine. Dietary Reference Intakes for Calcium and Vitamin D; Institute of Medicine, Food and Nutrition Board, Committee to Review Dietary Reference Intakes for Vitamin D and Calcium, Ross, A.C., Taylor, C.L., Yaktine, A.L., Del Valle, H.B., Eds.; National Academies Press: Washington, DC, USA, 2011.

82. EFSA Panel on Dietetic Products; Nutrition and Allergies (NDA). Dietary reference values for vitamin D. EFSA J. 2016, 14, e04547. [CrossRef]

83. EFSA Panel on Dietetic Products; Nutrition and Allergies (NDA). Scientific opinion on the tolerable upper intake level of vitamin D. EFSA J. 2012, 10, 2813.

84. EFSA Panel on Dietetic, Products; Nutrition and Allergies (EFSA NDA, Panel); Turck, D.; Bresson, J.L.; Burlingame, B.; Dean, T.; Fairweather-Tait, S.; Heinonen, M.; Hirsch-Ernst, K.I.; Mangelsdorf, I.; et al. Update of the tolerable upper intake level for vitamin D for infants. EFSA J. 2018, 16, e05365.

(C) 2020 by the authors. Licensee MDPI, Basel, Switzerland. This article is an open access article distributed under the terms and conditions of the Creative Commons Attribution (CC BY) license (http://creativecommons.org/licenses/by/4.0/). 